vanic element, conclusively ascertained that the conductor was in perfect working order right up to the top of the mountain, we began the descent and the return journey as rapidly as possible. We had no other choice, as the storm and rain which every moment increased precluded every possibility of doing more at that time. I had, however, some consolation in what already was done, my apparatus standing I 900 feet above the disks.

I left all the instruments to be used in connection with the experiments at Mogilsau in hopes that the weather would soon improve and allow me to return. The journey to Reykjavik was performed in a downpour of rain and a great storm.

As I had anticipated, the "utströmnings" apparatus has up to the present shown no signs of life whatever. I can see it plainly with a good telescope from my residence, and thus ascertain that it is in perfect order. In addition, I have just received a message from Mogilsau, informing me that the lower part is in perfect order too. Still during the few favourable nights we have as yet experienced not the slightest luminosity has appeared above the point in question.

If this be a negative result, it is a result, nevertheless, of considerable scientific interest.

The aurora borealis here has during the last few months been far more distinct in its appearance than during the first half of the winter. There is certainly, when the sky is sufficiently free from clouds, here and there a faint indication that the phenomenon does still exist, but such signs of life are very weak and limited.

I have at present no knowledge whether the aurora borealis has displayed less activity in other quarters of the globe during the winter than is generally the case, as letters take a long time from and to this island, but the Reykjavik people contend that the phenomenon displays usually far more energy and intensity than has been the case this winter. I am at present inquiring in various parts of the island whether the absence of the aurora borealis this winter has been noticed as generally remarkable, or its appearance is the usual one in Iceland.

In my last communication to NATURE I intended to have mentioned that I was curious to know what the effect would be of a sufficiently strong aurora covering the moon's disk. During the winter I have had several opportunities of observing aurore projecting over the disk of the moon when full, but nothing more unusual is seen than the light of the aurora borcalis disappearing within a radius of $5^{\circ}$ to $10^{\circ}$ around the moon. But in the appearance of the latter there is no difference.

Reykjavik, March

SOPHUS TROMHOLT

\section{A CARNIVOROUS PLANT PREYING ON} VERTEBRATA

$\mathrm{A}$ $\mathrm{N}$ interesting discovery has been made during the last week by Mr. G. E. Simms, son of a well-known tradesman of Oxford. It is that the bladder-traps of Utricularia vulgaris are capable of catching newlyhatched fish and killing them. Mr. Simms brought to me for examination a specimen of Utricularia in a glass vessel, in which were numerous young roach newly hatched from a mass of spawn lying at the bottom. Numbers of these young fish were seen dead, held fast in the jaws of the bladder-traps of the plant. I had never seen Utricularia before, and am indebted to my colleague Prof. Burdon Sanderson for the identification of the plant and a reference to Cohn's researches on it. Mr. Simms supplied me with a fresh specimen of Utricularia in a vessel with fresh young fish and spawn, and in about six hours more than a dozen of the fish were found entrapped. Most are caught by the head, and when this is the case the head is usually pushed as far into the bladder as possible till the snout touches its hinder wall. The two dark black eyes of the fish then show out conspicuously through the wall of the bladder. Rarely a specimen is seen caught only by the tip of the snout. By no means a few of the fish are, however, captured by the tail, which is swallowed, so to speak, to a greater or less distance, and I have one specimen in which the fish is caught by the yelk sac. Three or four instances were observed in which a fish had its head swallowed by one bladder-trap, and its tail by another adjacent one, the body of the fish forming a connecting bar between the two bladders.

$I$ have not been able to see a fish in the actual process of being trapped, nor to find onc recently caught, and showing by motion of the fore part of its body signs of life. All those trapped were found already dead, but I have had no opportunity of prolonged observation, and it will be remembered that Mr. Darwin, in his account of the trapping of Crustacea, worms, \&c., by Utricularia, states that he was not able to observe the actual occurrence of the trapping of an animal, although Mrs. Treat of New Jersey often did so. I think it probable that the fact described by Mr. Darwin, and which is easily verified, that the longer of the two pairs of projections composing the quadrifid processes by which the bladders of Utricularia are lined "project obliquely inwards and towards the posterior end of the bladder," has something to do with mechanism by which the small fish become so deeply swallowed so to speak. The oblique processes, set all towards the hinder end of the bladder, look as if they must act together with the spring valves of the mouth of the bladder in utilising each fresh struggle of the captive for the purpose of pushing it further and further inwards. On cutting open longitudinally some of the bladders containing the heads and foreparts of the bodies of fish, and examining their contents, I found the tissues of the fish in a more or less slimy deliquescent condition, no doubt from decomposition, for Mr. Darwin failed to detect any digestive process in Utricularia. The quadrifid processes were bathed in the slimy semi-fluid animal substance, and the processes themselves appeared to contain abundance of fine granular matter, possibly the result of absorption, but the large quantity of surrounding animal matter present rendered the observation uncertain. The usual swarms of Infusoria were present in the decomposing matter.

Specimens of the Utricularia with the little fish fast in the bladder-trap, and their heads or tails hanging out, can be well preserved in spirits, and show the conditions well, notwithstanding that the plant becomes colourless, and there is no longer the marked contrast between the glistening white dead fish and the green bladders, which in the fresh condition renders the combination of the trap and prey conspicuous.

Mr. Simms, by whose permission I write this, intends shortly to publish an account of his observations himself. I have advised him to endeavour to prepare spirit specimens of Utricularia plants with numerous trapped fish in situ for sale to those interested in the matter who may care to apply for them. His address is 37, Broad Street, Oxford.

H. N. MOSELEY

\section{NOTES}

M. PASTEL read to the Academy of Sciences on Monday an account of his experiments on rabies. He maintains that he has twenty dogs which he has rendered insusceptible to the disease, and which, with twenty ordinary dogs, he is prepared to have bitten by a number of dogs in a rabid state. $\Lambda$ Commission has been appointed by the French Government to test M. Pasteur's conclusions, the immense importance of which, if established, must be evident to every one. Eminent physiologists maintain, however, that M. Pasteur is far from having proved his position, and that it would be rash to give any positive opinion upon the subject until the experiment which he suggests has been made. We await the full report of $M$. Pasteur's paper before saying more upon 